\title{
G protein beta 3(GNB3) C825T polymorphism and irritable bowel syndrome susceptibility: an updated meta-analysis based on eleven case-control studies
}

\author{
Dongbo Jiang ${ }^{1, *}$, Dong Huang ${ }^{1, *}$, Weiming Cai ${ }^{1,2}$, Ting $\mathbf{L i}^{1}$, Yan Wang ${ }^{1}$, Huayan \\ Chen ${ }^{1}$, Tangming Guan ${ }^{1,2}$ and Xiaoli Ma ${ }^{1,3}$ \\ ${ }^{1}$ Department of Pharmacy, Affiliated Hospital of Guangdong Medical University, Zhanjiang, Guangdong Province 524001, \\ China \\ ${ }^{2}$ Laboratory of Clinical Pharmacy, Guangdong Medical University, Zhanjiang, Guangdong Province 524001, China \\ ${ }^{3}$ Department of Clinical Pharmacy, Guangdong Medical University, Zhanjiang, Guangdong Province 524001, China \\ *These authors contributed equally to this work \\ Correspondence to: Tangming Guan, email: gdmcgtm@163.com \\ Xiaoli Ma, email: gdmu_maxiaoli@163.com
}

Keywords: GNB3; polymorphism; irritable bowel syndrome; case-control; meta-analysis

Received: September 06, 2017 Accepted: October 31, 2017 Published: December 15, 2017

Copyright: Jiang et al. This is an open-access article distributed under the terms of the Creative Commons Attribution License 3.0 (CC BY 3.0), which permits unrestricted use, distribution, and reproduction in any medium, provided the original author and source are credited.

\section{ABSTRACT}

Several studies have reported an association between GNB3 C825T polymorphism and irritable bowel syndrome (IBS). However, the results remain inconclusive and controversial, particularly for the data derived from different ethnicities and IBS subtypes. Therefore, we performed an updated meta-analysis to evaluate this association. All eligible case-control studies that met the search criteria were retrieved from multiple databases, and eleven case-control studies were included for detailed evaluation. The pooled odds ratios (ORs) with $95 \%$ confidence intervals ( $95 \%$ CIs) were calculated to assess the strengths of the association between GN 33 C825T polymorphism and susceptibility to IBS and its subtypes. Our meta-analysis found no significantly associations of GNB3 C825T polymorphism with IBS risk in all populations. Whereas the $\mathrm{C}$ allele was demonstrated to be a decreased risk factor for constipation predominant IBS (IBS-C) in allele model. Additionally, the CC genotype was found to be associated with increased diarrhea predominant IBS (IBS-D) risk in recessive model. Subgroup analysis by ethnicity revealed that these associations held true for the Asian subpopulation. In conclusion, this meta-analysis suggests the C allele of GNB3 C825T might be associated with a decreased risk of IBS-C, and the CC genotype of GNB3 might be associated with increased IBS-D risk.

\section{INTRODUCTION}

Irritable bowel syndrome (IBS) is the most prevalent gastrointestinal disorder characterized by abdominal discomfort, pain, and altered defecation patterns; it may considerably reduce patients' quality of life and work productivity, which affects more than 7 percent of people all around the world $[1,2]$. According to the recurrent symptoms, IBS patients can experience constipation (IBS-C), diarrhea (IBS-D), mixture of diarrhea and constipation IBS (IBS-M) and un-subtyped IBS [3, 4]. IBS is a multifactorial disorder that is associated with biological and psychosocial factors [5-7]. Although genetic predisposition has been demonstrated in classical family and twin studies, unequivocal susceptibility genes have yet to be identified $[2,8]$. Recently, several genetic association studies identified the guanine nucleotide binding protein (G-protein) $\beta 3$ subunit gene (GN/33) C825T polymorphism as being significantly associated with IBS [9-12].

G-protein, consisting of an $\alpha, \beta$, and $\gamma$ subunit, is an intracellular second messenger signalling protein linked to a transmembrane receptor $[13,14]$. The C825T polymorphism of GNB3 (rs5443) is associated with 
alternative splicing of the gene and its protein activity, and an increased intracellular signal transduction compared with unmodified G $\beta 3$ protein $[15,16]$. This single nucleotide polymorphism (SNP) has been reported to be associated with depression [17], Alzheimer's disease (AD) [18], hypertension [19], obesity [20], Insulin-mediated venodilation [21], Vasculogenic erectile dysfunction (VED) [22], and functional dyspepsia [23]. Recently, the association between the GNB3 C825T polymorphism and the risk of IBS has been intensively investigated. However, the community is still unable to reach a consensus, particularly regarding the data from different ethnicities and IBS subtypes [9-12, 24-30]. To date, only one meta-analyses has reported on the relationship between GNB3 C825T polymorphism and susceptibility to IBS [31]. However, that meta-analysis only included seven studies, and missed many published articles [2730]. Moreover, the previous meta-analysis did not analyze the association between GN 33 C825T polymorphism and different IBS subtypes with respect to ethnicity. Therefore, we conducted an updated meta-analysis including all published studies accompanied with ethnic subgroup analyses and IBS subtype analyses to clarify whether GN 33 C 825T was associated with the development of IBS and its subtypes.

\section{RESULTS}

\section{Characteristics of studies 26-9-11}

As showed in Figure 1, eleven studies involving 1,422 cases and 2,073 controls were ultimately included in the present meta-analysis, and eight of them $[10,12$, $24,25,27-30]$ specifically investigated the association between GNB3 C825T polymorphism and different IBS subtypes (including the IBS-C, IBS-D and IBS-M) risk. The main characteristics of the included articles were summarized in Table 1. All of these included articles were case-control studies, of which nine in a hospital-based design [10-12, 25-30], two in a population-based design $[9,24]$. Among these studies, six were on Caucasians [9, $11,24,25,27,28]$ and the other five were on Asians [10, $12,26,29,30]$. Additionally, all of the included studies were of high quality, as indicated by the Newcastle-Ottawa scale (NOS) scores of each study being above 6 points, and the genotype distributions in all of the controls were consistent with Hardy-Weinberg equilibrium (HWE), except one [10]. Studies with controls not in HWE were also considered for the meta-analysis, but they were excluded in the sensitivity analysis.

\section{Power analysis}

Before implementation of this meta-analysis, statistical power was assessed with the assumptions: $\alpha$ err prob $=0.05$, $\mathrm{OR}=1.25$ (corresponding to a "weak to moderate" gene effect) for the SNP, and minor allele frequencies(MAF) of GNB3 C825T(rs5443, C/T) was estimated from the 1000 Genomes. The present samples indicated that $100 \%$ power to evaluate the association between this polymorphism and IBS. And the power to evaluate the associations between this polymorphism and IBS subtypes (IBS-C, IBS-D and IBS-M) were $88.1 \%, 98.3 \%$ and $93.9 \%$, respectively. The power analysis indicated that these recruited samples could provide sufficient power in identifying the association between GNB3 C825T(rs5443, C/T) polymorphism and IBS and its subtypes.

\section{Quantitative synthesis}

\section{GNB3 C825T and IBS risk}

Overall, no significant association between $G N \beta 3$ C825T polymorphism and risk of IBS was observed under all genetic models $(\mathrm{C}$ vs. T, $P=0.194$; $\mathrm{CC}$ vs. TT, $P=$ 0.564 ; CT vs. TT, $P=0.594 ; \mathrm{CC}+\mathrm{CT}$ vs. TT, $P=0.430$; $\mathrm{CC}$ vs. CT+TT, $P=0.462$ ) (Figure 2 ). In the subgroup analyses by ethnicity, significant associations were not found in any genetic model for Asians and Caucasians. All the results are listed in Table 2.

\section{GN/3 C825T and IBS-C risk}

The $\mathrm{C}$ allele of GNB3 C825T was found to be significantly associated with a decreased risk of IBS-C in allele model (C vs. T, OR $=0.788,95 \%$ CI: $0.622-$ $0.997, P=0.048$ ), while no evidence of significance was identified in other genetic models (CC vs. TT, $P=0.073$; $\mathrm{CT}$ vs. TT, $P=0.140 ; \mathrm{CC}+\mathrm{CT}$ vs. TT, $P=0.056 ; \mathrm{CC}$ vs. $\mathrm{CT}+\mathrm{TT}, P=0.292$ ). In the subgroup analyses by ethnicity, the significant association was found among Asians under all genetic models ( $\mathrm{C}$ vs. T, OR $=0.520,95 \%$ CI: 0.329 $0.821, P=0.005$; CC vs. TT, OR $=0.258,95 \%$ CI: $0.094-$ $0.707, P=0.008$; CT vs. TT, OR $=0.431,95 \%$ CI: 0.221 $0.842, P=0.014 ; \mathrm{CC}+\mathrm{CT}$ vs. TT, $\mathrm{OR}=0.378,95 \% \mathrm{CI}$ : $0.200-0.714, P=0.003)$ except for the recessive model (CC vs. CT+TT, $P=0.126$ ) (Figure 3). However, there was no significant association between this polymorphism and IBS-C development in the Caucasian population under any genetic model. All the results are listed in Table 2.

\section{GNB3 C825T and IBS-D risk}

The CC genotype of GN $\beta 3$ C $825 \mathrm{~T}$ was found to be significantly associated with an increased risk of IBS-D in recessive model $(\mathrm{CC}$ vs. $\mathrm{CT}+\mathrm{TT}, \mathrm{OR}=1.268$, 95\% CI: $1.000-1.608, P=0.050$ ), while no evidence of significance was identified in other genetic models (C vs. T, $P=0.089$; CC vs. TT, $P=0.236$; CT vs. TT, $P=0.345$; $\mathrm{CC}+\mathrm{CT}$ vs. TT, $P=0.980$ ). In the subgroup analyses by ethnicity, the significant association was found among 


\begin{tabular}{|c|c|c|c|c|c|c|c|c|c|c|c|}
\hline \multirow[t]{2}{*}{ Study } & \multirow[t]{2}{*}{ Country } & \multirow[t]{2}{*}{ Ethnicity } & \multirow[t]{2}{*}{ Design } & \multirow{2}{*}{$\begin{array}{c}\text { Gender } \\
(\mathrm{M}: \mathrm{F}[\mathrm{n}]) \\
\text { (case/ } \\
\text { control) }\end{array}$} & \multicolumn{3}{|c|}{$\begin{array}{c}\text { Genotype } \\
\text { distribution (case/ } \\
\text { control) } \\
\end{array}$} & \multirow{2}{*}{$\begin{array}{l}\text { Genotyping } \\
\text { Method }\end{array}$} & \multirow{2}{*}{$\begin{array}{l}\text { Diagnosis } \\
\text { criteria }\end{array}$} & \multirow{2}{*}{$\begin{array}{l}\text { HWE } \\
\text { (P) }\end{array}$} & \multirow[t]{2}{*}{ NOS } \\
\hline & & & & & $\mathrm{CC}$ & CT & TT & & & & \\
\hline $\begin{array}{c}\text { Andresen V } \\
2006\end{array}$ & $\begin{array}{l}\text { United } \\
\text { States }\end{array}$ & $\begin{array}{c}\text { Caucasian } \\
(95.1 \%)\end{array}$ & PB & $\begin{array}{c}31: 183 / \\
40: 112\end{array}$ & $\begin{array}{c}111 / \\
77\end{array}$ & $\begin{array}{l}87 / \\
62\end{array}$ & $\begin{array}{c}16 / \\
13\end{array}$ & $\begin{array}{c}\text { Direct } \\
\text { Sequencing }\end{array}$ & Rome II & 0.92 & 9 \\
\hline $\begin{array}{c}\text { Camilleri M } \\
2008\end{array}$ & $\begin{array}{l}\text { United } \\
\text { States }\end{array}$ & Caucasian & $\mathrm{HB}$ & $\begin{array}{c}3: 119 / \\
0: 39\end{array}$ & $\begin{array}{c}57 / \\
19\end{array}$ & $\begin{array}{c}53 / \\
16\end{array}$ & $\begin{array}{c}12 / \\
4\end{array}$ & $\begin{array}{c}\text { Direct } \\
\text { Sequencing }\end{array}$ & Rome II & 0.82 & 7 \\
\hline $\begin{array}{c}\text { de Vries DR } \\
2009\end{array}$ & Netherlands & Caucasian & PB & $\begin{array}{c}66: 70 / \\
120: 253\end{array}$ & $\begin{array}{l}60 / \\
199\end{array}$ & $\begin{array}{l}68 / \\
138\end{array}$ & $\begin{array}{l}8 / \\
36\end{array}$ & $\begin{array}{c}\text { molecular } \\
\text { beacon assay }\end{array}$ & Rome II & 0.10 & 8 \\
\hline Kim HG 2012 & South Korea & Asian & $\mathrm{HB}$ & $\begin{array}{l}25: 35 / \\
167: 267\end{array}$ & $\begin{array}{l}16 / \\
112\end{array}$ & $\begin{array}{l}31 / \\
215\end{array}$ & $\begin{array}{l}13 / \\
107\end{array}$ & $\begin{array}{c}\text { TaqMan } \\
\text { Assay }\end{array}$ & Rome III & 0.85 & 7 \\
\hline Lee HJ 2010 & South Korea & Asian & $\mathrm{HB}$ & $\begin{array}{c}58: 36 / \\
44: 44\end{array}$ & $\begin{array}{l}13 / \\
16\end{array}$ & $\begin{array}{c}49 / \\
56\end{array}$ & $\begin{array}{l}32 / \\
16\end{array}$ & $\begin{array}{l}\text { PCR and } \\
\text { RFLP }\end{array}$ & Rome III & 0.01 & 7 \\
\hline $\begin{array}{c}\text { Markoutsaki T } \\
2011\end{array}$ & Greece & Caucasian & $\mathrm{HB}$ & $\begin{array}{l}30: 94 / \\
96: 142\end{array}$ & $\begin{array}{l}37 / \\
120\end{array}$ & $\begin{array}{r}65 / \\
97\end{array}$ & $\begin{array}{r}22 / \\
21\end{array}$ & $\begin{array}{l}\text { PCR and } \\
\text { RFLP }\end{array}$ & Rome III & 0.82 & 7 \\
\hline Park CS 2012 & South Korea & Asian & HB & $\begin{array}{l}32: 40 / \\
81: 67\end{array}$ & $\begin{array}{l}27 / \\
35\end{array}$ & $\begin{array}{r}28 / \\
79\end{array}$ & $\begin{array}{l}17 / \\
34\end{array}$ & SNaPShot & Rome III & 0.41 & 7 \\
\hline Saito YA 2007 & $\begin{array}{l}\text { United } \\
\text { States }\end{array}$ & $\begin{array}{c}\text { Caucasian } \\
(>96 \%)\end{array}$ & HB & $\begin{array}{l}9: 41 / \\
10: 43\end{array}$ & $\begin{array}{l}25 / \\
24\end{array}$ & $\begin{array}{r}19 / \\
22\end{array}$ & $\begin{array}{r}6 / \\
7\end{array}$ & $\begin{array}{c}\text { Thermo } \\
\text { Electron } \\
\text { Hybaid MBS } \\
\text { thermal cycler }\end{array}$ & Rome II & 0.59 & 7 \\
\hline Saito YA 2012 & $\begin{array}{l}\text { United } \\
\text { States }\end{array}$ & $\begin{array}{c}\text { Caucasian } \\
(>97 \%)\end{array}$ & HB & $\begin{array}{l}65: 320 / \\
84: 178\end{array}$ & $\begin{array}{l}122 / \\
114\end{array}$ & $\begin{array}{l}117 / \\
109\end{array}$ & $\begin{array}{l}28 / \\
28\end{array}$ & $\begin{array}{c}\text { Thermo } \\
\text { Electron } \\
\text { Hybaid MBS } \\
\text { thermal cycler }\end{array}$ & Rome II & 0.80 & 7 \\
\hline $\begin{array}{c}\text { Yoon Jin Choi } \\
2014\end{array}$ & South Korea & Asian & $\mathrm{HB}$ & $\begin{array}{l}38: 61 / \\
85: 86\end{array}$ & $\begin{array}{c}26 / \\
40\end{array}$ & $\begin{array}{c}46 / \\
81\end{array}$ & $\begin{array}{c}27 / \\
50\end{array}$ & $\begin{array}{c}\text { TaqMan } \\
\text { Assay }\end{array}$ & Rome III & 0.52 & 8 \\
\hline $\begin{array}{c}\text { Yuezhi Wang } \\
2014 \\
\end{array}$ & China & Asian & HB & $\begin{array}{l}56: 10 / \\
89: 26 \\
\end{array}$ & $\begin{array}{l}50 / \\
92 \\
\end{array}$ & $\begin{array}{l}13 / \\
21 \\
\end{array}$ & $\begin{array}{r}3 / \\
2 \\
\end{array}$ & $\begin{array}{c}\text { Real-Time } \\
\text { PCR }\end{array}$ & Rome III & 0.54 & 7 \\
\hline
\end{tabular}

Abbreviations: HB, hospital-based study; PB, population based; RFLP, restriction fragment length polymorphism analyses

Asians under allele model (C vs. T, OR $=1.316,95 \% \mathrm{CI}$ : $1.019-1.700, P=0.035$ ) and recessive model (CC vs. $\mathrm{CT}+\mathrm{TT}, \mathrm{OR}=1.688,95 \% \mathrm{CI}: 1.157-2.463, P=0.007)$, while no evidence of significance was identified in other two genetic models (Figure 4). However, there was no significant association between this polymorphism and IBS-D development in the Caucasian population under any genetic model. All the results are listed in Table 2.

\section{GNB3 C825T and IBS-M risk}

No significant association was found between GN $\beta 3$ C825T polymorphism and IBS-M in the overall population. In subgroup analysis, there was no significant association between this polymorphism and IBS-M development in the Caucasian and Asian population. All the results are listed in Table 2 .

\section{Sensitivity analysis}

Sensitivity analysis of the summary odds ratio coefficients on the relationship of the SNP and the risk of IBS is computed by omitting each study in turn. The corresponding pooled ORs were not significantly altered after excluding each eligible study at a time (Figure 5).

\section{Publication bias}

No evidence of publication bias was detected regarding the ORs of the SNP in this study by either Begg's or Egger's test (Table 3).

\section{DISCUSSION}

Recently, several genetic association studies identified a novel association between GNB3 C825T 
Table 2: Summary of meta-analysis for the association of GNB3 C825T polymorphism with IBS and its subtypes

\begin{tabular}{|c|c|c|c|c|c|c|}
\hline \multirow{2}{*}{ Genetic models } & \multirow{2}{*}{ Stratifications } & \multirow{2}{*}{$\begin{array}{c}\text { Number of } \\
\text { studies }\end{array}$} & \multirow{2}{*}{ OR $(95 \% C I)$} & \multirow{2}{*}{$P$ value } & \multicolumn{2}{|c|}{ Heterogeneity } \\
\hline & & & & & $I^{2}$ & $P_{H}$ \\
\hline \multicolumn{7}{|l|}{ IBS } \\
\hline \multirow[t]{3}{*}{ C vs. T } & Overall & 11 & $0.893[0.752,1.060]$ & 0.194 & $54.5 \%$ & 0.015 \\
\hline & Asians & 5 & $0.959[0.756,1.216]$ & 0.729 & $37.7 \%$ & 0.170 \\
\hline & Caucasian & 6 & $0.852[0.666,1.091]$ & 0.205 & $64.6 \%$ & 0.015 \\
\hline \multirow[t]{3}{*}{ CC vs. TT } & Overall & 11 & $0.906[0.649,1.266]$ & 0.564 & $45.6 \%$ & 0.049 \\
\hline & Asians & 5 & $0.960[0.583,1.580]$ & 0.872 & $36.9 \%$ & 0.175 \\
\hline & Caucasian & 6 & $0.879[0.543,1.421]$ & 0.599 & $57.0 \%$ & 0.040 \\
\hline \multirow[t]{3}{*}{ CT vs. TT } & Overall & 11 & $0.940[0.748,1.180]$ & 0.594 & $18.4 \%$ & 0.268 \\
\hline & Asians & 5 & $0.800[0.578,1.107]$ & 0.179 & $26.0 \%$ & 0.248 \\
\hline & Caucasian & 6 & $1.096[0.796,1.509]$ & 0.574 & $5.9 \%$ & 0.379 \\
\hline \multirow[t]{3}{*}{$\mathrm{CC}+\mathrm{CT}$ vs. TT } & Overall & 11 & $0.917[0.739,1.137]$ & 0.430 & $31.3 \%$ & 0.150 \\
\hline & Asians & 5 & $0.866[0.639,1.175]$ & 0.356 & $38.4 \%$ & 0.165 \\
\hline & Caucasian & 6 & $0.970[0.715,1.316]$ & 0.845 & $36.7 \%$ & 0.162 \\
\hline \multirow[t]{3}{*}{ CC vs. CT+TT } & Overall & 11 & $0.914[0.718,1.162]$ & 0.462 & $53.3 \%$ & 0.018 \\
\hline & Asians & 5 & $1.110[0.794,1.552]$ & 0.542 & $24.3 \%$ & 0.259 \\
\hline & Caucasian & 6 & $0.814[0.595,1.113]$ & 0.197 & $60.8 \%$ & 0.026 \\
\hline \multicolumn{7}{|l|}{ IBS-C } \\
\hline \multirow[t]{3}{*}{ C vs. T } & Overall & 8 & $0.788[0.622,0.997]$ & 0.048 & $24 \%$ & 0.238 \\
\hline & Asians & 4 & $0.520[0.329,0.821]$ & 0.005 & $0 \%$ & 0.503 \\
\hline & Caucasian & 4 & $0.926[0.701,1.225]$ & 0.592 & $0 \%$ & 0.461 \\
\hline \multirow[t]{3}{*}{ CC vs. TT } & Overall & 8 & $0.622[0.370,1.046]$ & 0.073 & $0 \%$ & 0.532 \\
\hline & Asians & 4 & $0.258[0.094,0.707]$ & 0.008 & $0 \%$ & 0.736 \\
\hline & Caucasian & 4 & $0.974[0.506,1.877]$ & 0.938 & $0 \%$ & 0.827 \\
\hline \multirow[t]{3}{*}{ CT vs. TT } & Overall & 8 & $0.709[0.449,1.120]$ & 0.140 & $0 \%$ & 0.552 \\
\hline & Asians & 4 & $0.431[0.221,0.842]$ & 0.014 & $0 \%$ & 0.749 \\
\hline & Caucasian & 4 & $1.094[0.571,2.093]$ & 0.787 & $0 \%$ & 0.839 \\
\hline \multirow[t]{3}{*}{$\mathrm{CC}+\mathrm{CT}$ vs. TT } & Overall & 8 & $0.653[0.422,1.011]$ & 0.056 & $6.4 \%$ & 0.381 \\
\hline & Asians & 4 & $0.378[0.200,0.714]$ & 0.003 & $0 \%$ & 0.652 \\
\hline & Caucasian & 4 & $1.035[0.556,1.929]$ & 0.913 & $0 \%$ & 0.848 \\
\hline \multirow[t]{3}{*}{ CC vs. $\mathrm{CT}+\mathrm{TT}$} & Overall & 8 & $0.835[0.597,1.168]$ & 0.292 & $0 \%$ & 0.731 \\
\hline & Asians & 4 & $0.513[0.218,1.208]$ & 0.126 & $0 \%$ & 0.668 \\
\hline & Caucasian & 4 & $0.927[0.641,1.340]$ & 0.686 & $0 \%$ & 0.621 \\
\hline \multicolumn{7}{|l|}{ IBS-D } \\
\hline \multirow[t]{3}{*}{ C vs. T } & Overall & 8 & $1.162[0.977,1.381]$ & 0.089 & $30.9 \%$ & 0.181 \\
\hline & Asians & 4 & $1.316[1.019,1.700]$ & 0.035 & $55.8 \%$ & 0.079 \\
\hline & Caucasian & 4 & $1.046[0.827,1.321]$ & 0.709 & $0 \%$ & 0.635 \\
\hline \multirow[t]{3}{*}{ CC vs. TT } & Overall & 8 & $1.246[0.866,1.793]$ & 0.236 & $14.8 \%$ & 0.314 \\
\hline & Asians & 4 & $1.609[0.963,2.690]$ & 0.069 & $43.9 \%$ & 0.148 \\
\hline & Caucasian & 4 & $0.957[0.571,1.603]$ & 0.867 & $0 \%$ & 0.802 \\
\hline \multirow[t]{3}{*}{ CT vs. TT } & Overall & 8 & $0.843[0.592,1.201]$ & 0.345 & $0 \%$ & 0.822 \\
\hline & Asians & 4 & $0.796[0.493,1.287]$ & 0.352 & $9.1 \%$ & 0.348 \\
\hline & Caucasian & 4 & $0.902[0.543,1.525]$ & 0.701 & $0 \%$ & 0.979 \\
\hline \multirow[t]{2}{*}{$\mathrm{CC}+\mathrm{CT}$ vs. TT } & Overall & 8 & $0.996[0.716,1.384]$ & 0.980 & $0 \%$ & 0.542 \\
\hline & Asians & 4 & $1.048[0.674,1.630]$ & 0.836 & $43.6 \%$ & 0.150 \\
\hline
\end{tabular}




\begin{tabular}{|c|c|c|c|c|c|c|}
\hline & Caucasian & 4 & $0.934[0.570,1.529]$ & 0.785 & $0 \%$ & 0.901 \\
\hline \multirow[t]{3}{*}{ CC vs. $\mathrm{CT}+\mathrm{TT}$} & Overall & 8 & $1.268[1.000,1.608]$ & 0.050 & $27.8 \%$ & 0.206 \\
\hline & Asians & 4 & $1.688[1.157,2.463]$ & 0.007 & $29.2 \%$ & 0.237 \\
\hline & Caucasian & 4 & $1.054[0.777,1.432]$ & 0.735 & $0 \%$ & 0.644 \\
\hline \multicolumn{7}{|l|}{ IBS-M } \\
\hline \multirow[t]{3}{*}{ C vs. T } & Overall & 8 & $0.789[0.576,1.080]$ & 0.139 & $51.5 \%$ & 0.044 \\
\hline & Asians & 4 & $0.672[0.403,1.121]$ & 0.128 & $50.1 \%$ & 0.111 \\
\hline & Caucasian & 4 & $0.926[0.660,1.299]$ & 0.655 & $34.5 \%$ & 0.205 \\
\hline \multirow[t]{3}{*}{ CC vs. TT } & Overall & 8 & $0.798[0.402,1.587]$ & 0.521 & $38.1 \%$ & 0.126 \\
\hline & Asians & 4 & $0.464[0.126,1.713]$ & 0.249 & $53.1 \%$ & 0.094 \\
\hline & Caucasian & 4 & $1.253[0.678,2.316]$ & 0.472 & $0.0 \%$ & 0.513 \\
\hline \multirow[t]{3}{*}{ CT vs. TT } & Overall & 8 & $0.994[0.662,1.495]$ & 0.979 & $0 \%$ & 0.614 \\
\hline & Asians & 4 & $0.755[0.431,1.325]$ & 0.327 & $0 \%$ & 0.622 \\
\hline & Caucasian & 4 & $1.337[0.732,2.440]$ & 0.345 & $0 \%$ & 0.540 \\
\hline \multirow[t]{3}{*}{$\mathrm{CC}+\mathrm{CT}$ vs. TT } & Overall & 8 & $0.941[0.639,1.387]$ & 0.760 & $11.6 \%$ & 0.340 \\
\hline & Asians & 4 & $0.689[0.404,1.174]$ & 0.170 & $9.5 \%$ & 0.346 \\
\hline & Caucasian & 4 & $1.306[0.736,2.318]$ & 0.361 & $0.0 \%$ & 0.529 \\
\hline \multirow[t]{3}{*}{ CC vs. $\mathrm{CT}+\mathrm{TT}$} & Overall & 8 & $0.788[0.500,1.240]$ & 0.303 & $45.2 \%$ & 0.078 \\
\hline & Asians & 4 & $0.622[0.216,1.789]$ & 0.378 & $61.5 \%$ & 0.050 \\
\hline & Caucasian & 4 & $0.935[0.623,1.403]$ & 0.746 & $21.6 \%$ & 0.281 \\
\hline
\end{tabular}

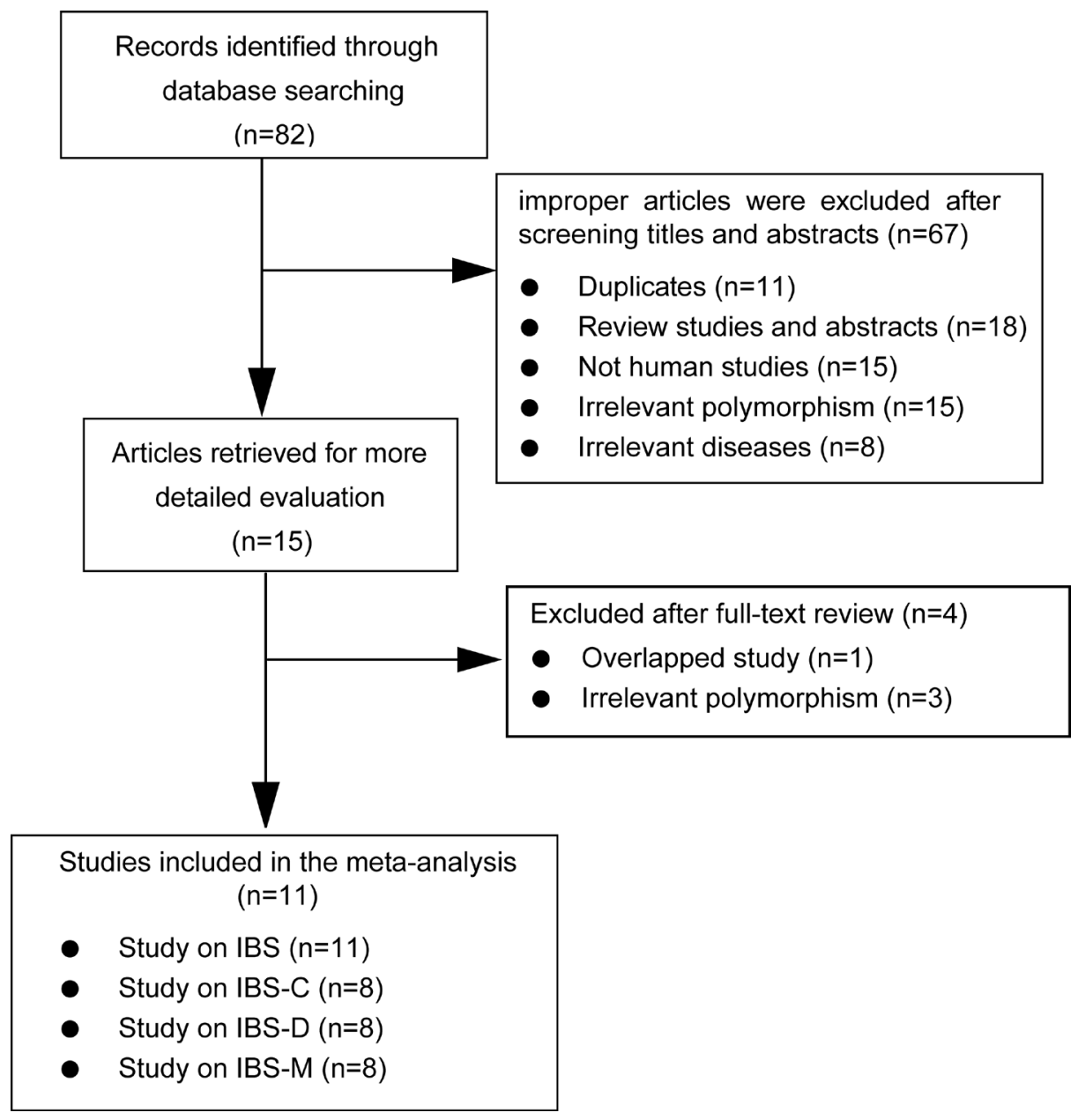

Figure 1: Flow diagram of selection of eligible studies. 
Table 3: Publication bias tests for association of the GNB3 C825T polymorphism with IBS

\begin{tabular}{lcccc} 
& \multicolumn{3}{c}{ Egger test } & Begg test \\
\cline { 2 - 4 } & Coefficient & P value & $\mathbf{9 5 \%}$ CI & P value \\
\hline GN33 C825T & 0.48 & 0.80 & $(-3.70,4.67)$ & 0.76 \\
C vs. T & -0.96 & 0.60 & $(-4.92,3.01)$ & 0.64 \\
CC vs. TT & -0.22 & 0.87 & $(-3.02,2.59)$ & 0.76 \\
CT vs. TT & -0.34 & 0.80 & $(-3.39,2.70)$ & 0.64 \\
CC+CT vs. TT & 0.93 & 0.59 & $(-2.75,4.64)$ & 0.64 \\
CC vs. CT+TT & & & & \\
\hline
\end{tabular}
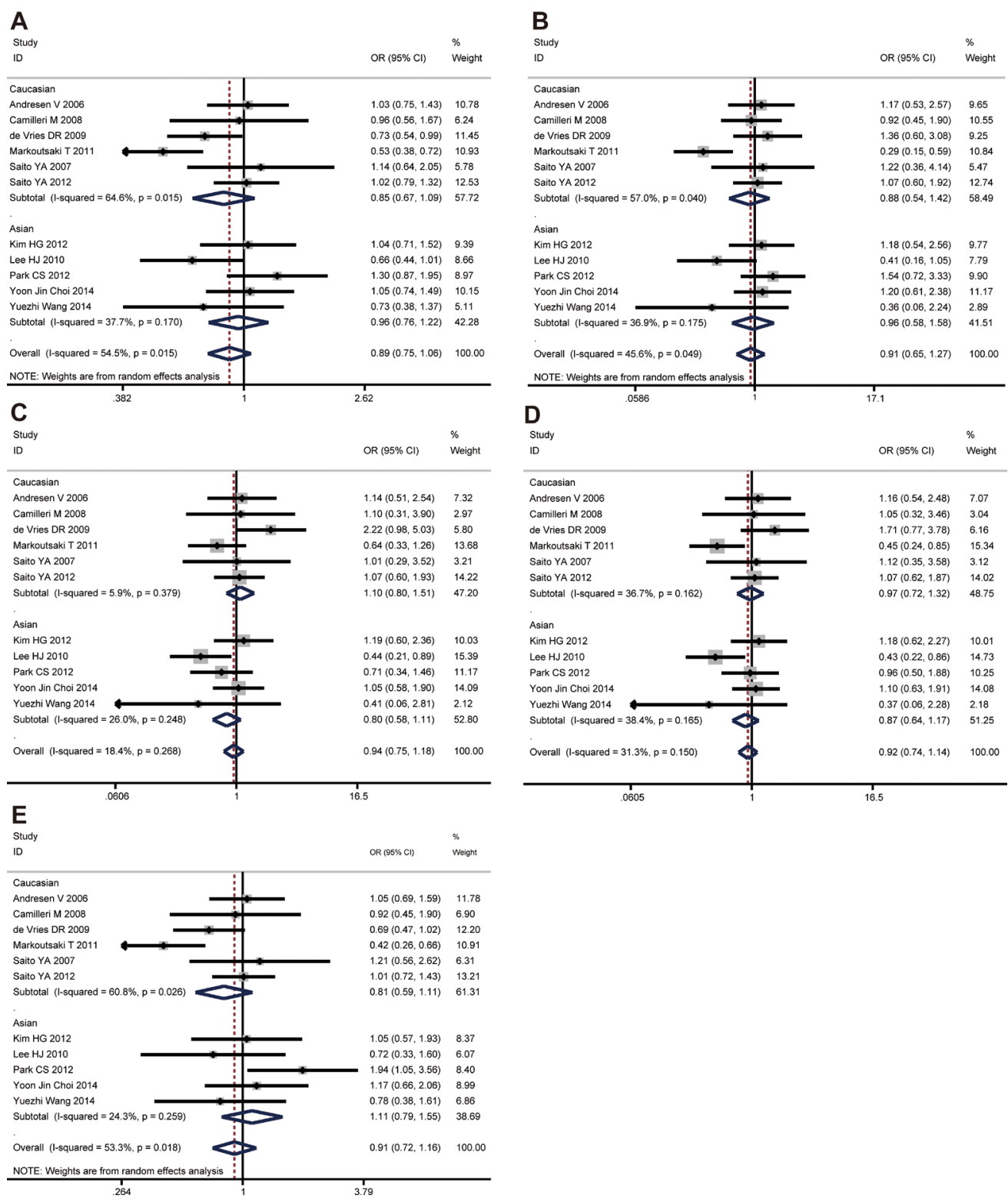

Figure 2: The associations of GNB3 C825T with IBS in different genetic models. (A) Allele model (C vs. T). (B) Codominant model (CC vs. TT). (C) Codominant model (CT vs. TT). (D) Dominant model (CC + CT vs. TT). (E) Recessive model (CC vs. TT + CT). 
polymorphism and IBS. In Asia, Lee et al. [10] demonstrated that GNB3 825T allele is associated with IBS in Koreans, especially among IBS with constipation. Likewise, Park et al. [12] found that the TT genotype of GNR3 C825T is common in IBS-C while the CC genotype is common in IBS-D. In Europe, Markoutsaki $\mathrm{T}$ [11] found that TT genotype and T allele of GNR3 are significantly associated with IBS predisposition in Greeks. Besides, in a Netherlands study CT genotype of GNR3 showed significant association with IBS [9]. However, other studies [24-30] revealed that the GNB3 C825T polymorphism may be not associated with the

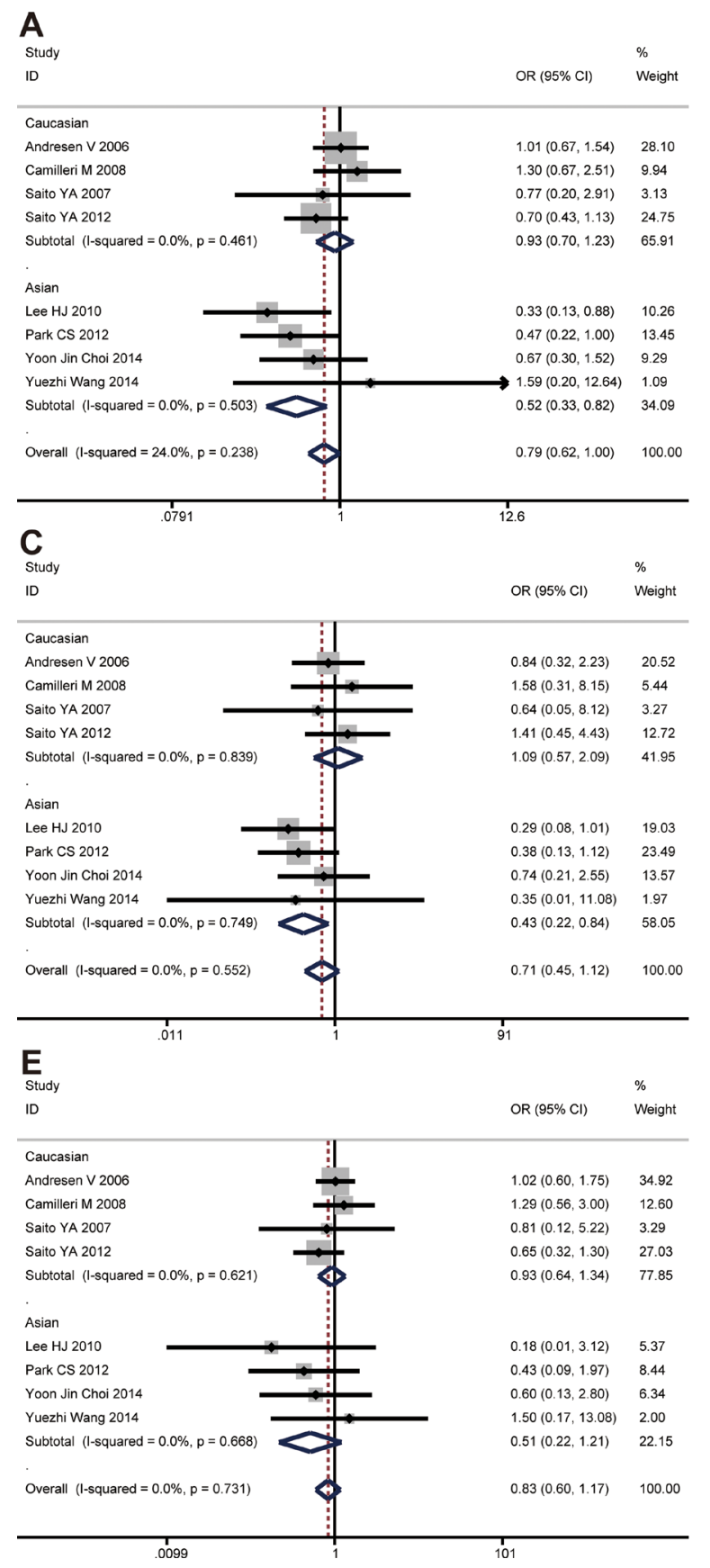

development of IBS or its subtypes. Generally, this disparity might be partly due to ethnic differences or to the limited numbers of subjects involved in the studies. To derive a more precise estimation of this association, we performed a meta-analysis to clarify the associations between the GNB3 C825T mutation and the presence of IBS and its subtypes. Eleven casecontrol studies [9-12, 24-30] with a total of 1,422 IBS patients and 2,073 healthy controls were included in our meta-analysis, which was sufficiently powered to detect IBS susceptibility associated with GNB3 C825T gene polymorphism.

B

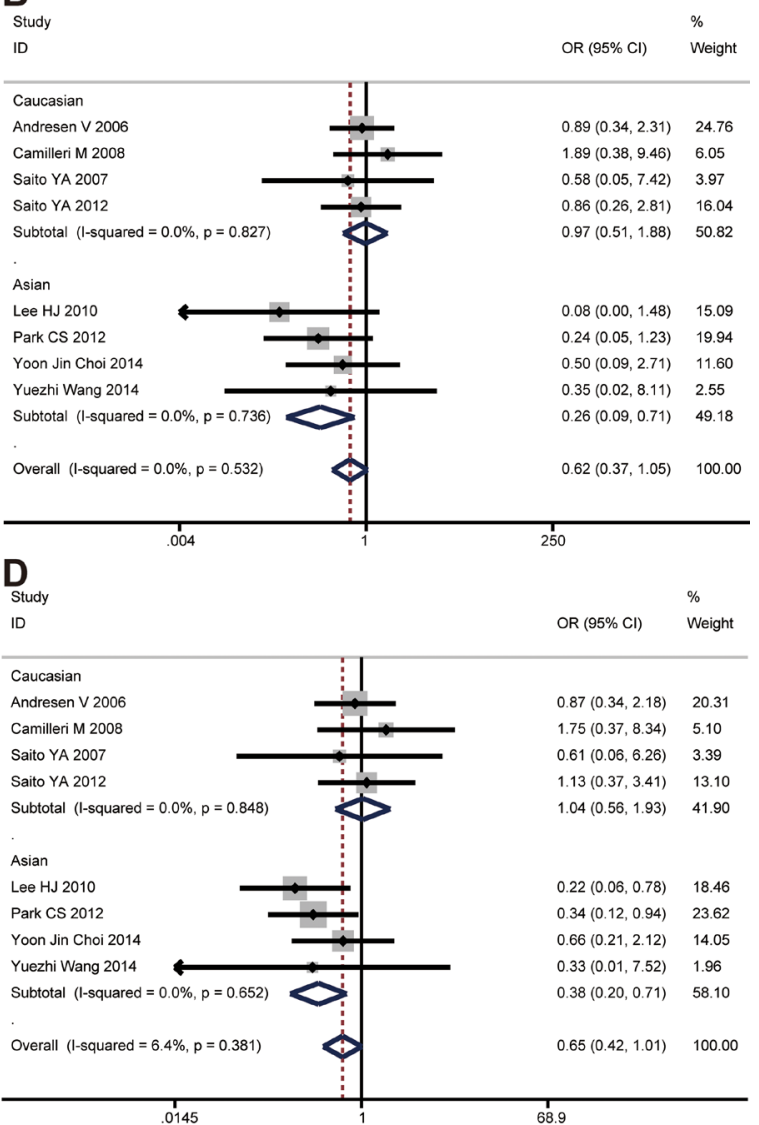

Figure 3: The associations of GNB3 C825T with IBS-C in different genetic models. (A) Allele model (C vs. T). (B) Codominant model (CC vs. TT). (C) Codominant model (CT vs. TT). (D) Dominant model (CC + CT vs. TT). (E) Recessive model (CC vs. TT + CT). 
In the present study, we used four models to estimate the relationship between GNB3 C825T polymorphism and IBS and its subtypes. The C allele of GN 33 C825T was demonstrated to be significantly associated with a decreased risk of IBS-C in allele model. While the results of the recessive model supported CC genotype of GN $\beta 3$ could increase the risk of IBS-D. Additionally, subgroup analyses by ethnicity indicated that the SNP of GN $\beta 3$ C825T was only significantly associated with a decreased risk of IBS-C in Asian population, while the CC genotype was only associated with increased IBS-D risk in the Asian population. Besides that, neither the overall results with the whole population nor the subgroup analysis by Asian and Caucasian ethnicity indicated the associations between
GN $\beta 3$ C825T polymorphism and the development of IBS and IBS-M. Obviously, our results are not consistent with some previous studies [9-12] that GN $\beta 3$ C825T was associated with IBS. A possible explanation for this phenomenon is that the previous single studies of IBS had small samples size, and thus the significance of current work may not be justified; thus, further studies are needed to clarify the effects of this SNP on the development of IBS and its subtypes. In addition, the differential allele frequencies of the SNP exerted disproportionate levels of influence on the IBS risks in different populations. For example, the minor allele frequencies (MAF) of the SNP $G N \beta 3$ C825T (rs5443) is 0.50 in the East Asian population (EAS), whereas the MAF is 0.31 in the European

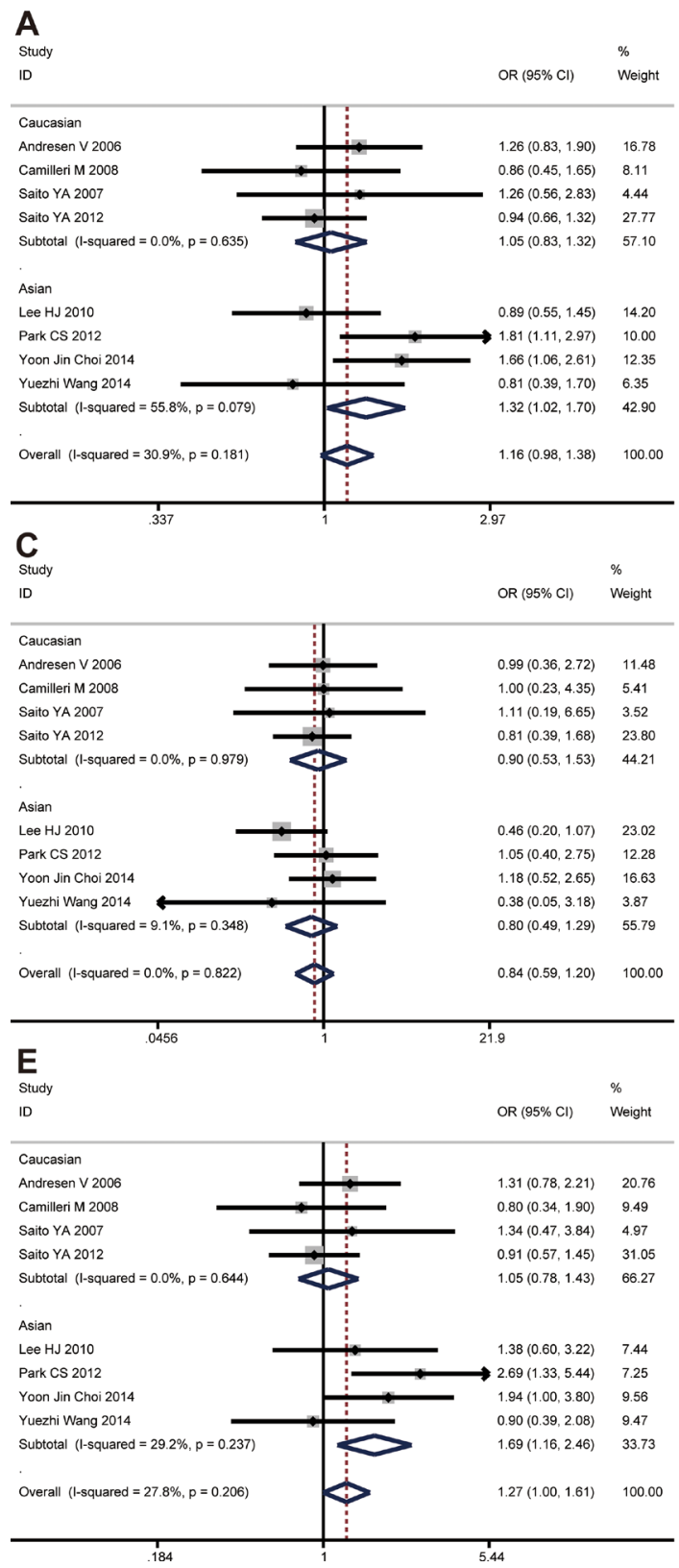

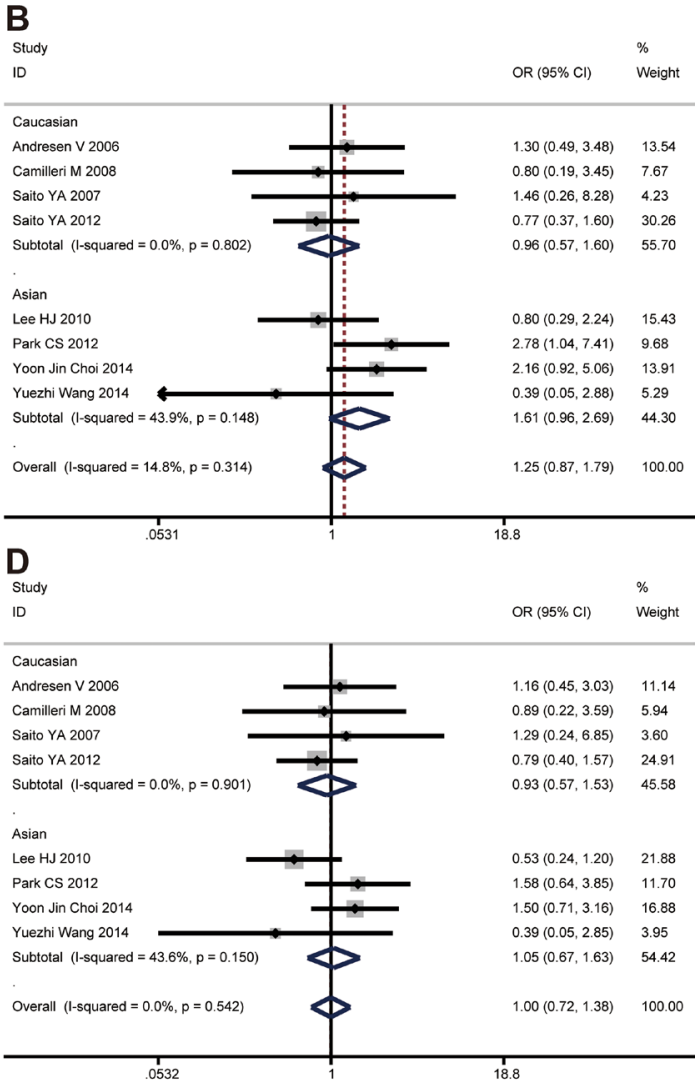


population (EUR) and the MAF is 0.38 in the Ad Mixed American population (AMR) based on the data from the $1000 \mathrm{G}$. In accordance with our partial findings, a previous meta-analysis performed by Pan ZG et al. [31] found that no associations of GNB3 C825T polymorphism with IBS risk either in Asian population or Caucasian population. However, that previous meta-analysis based on seven studies still had some differences from our results, and suggested that no significant associations between $G N \beta 3$ C825T polymorphism and 3 IBS subtypes (IBS-C, IBS-D
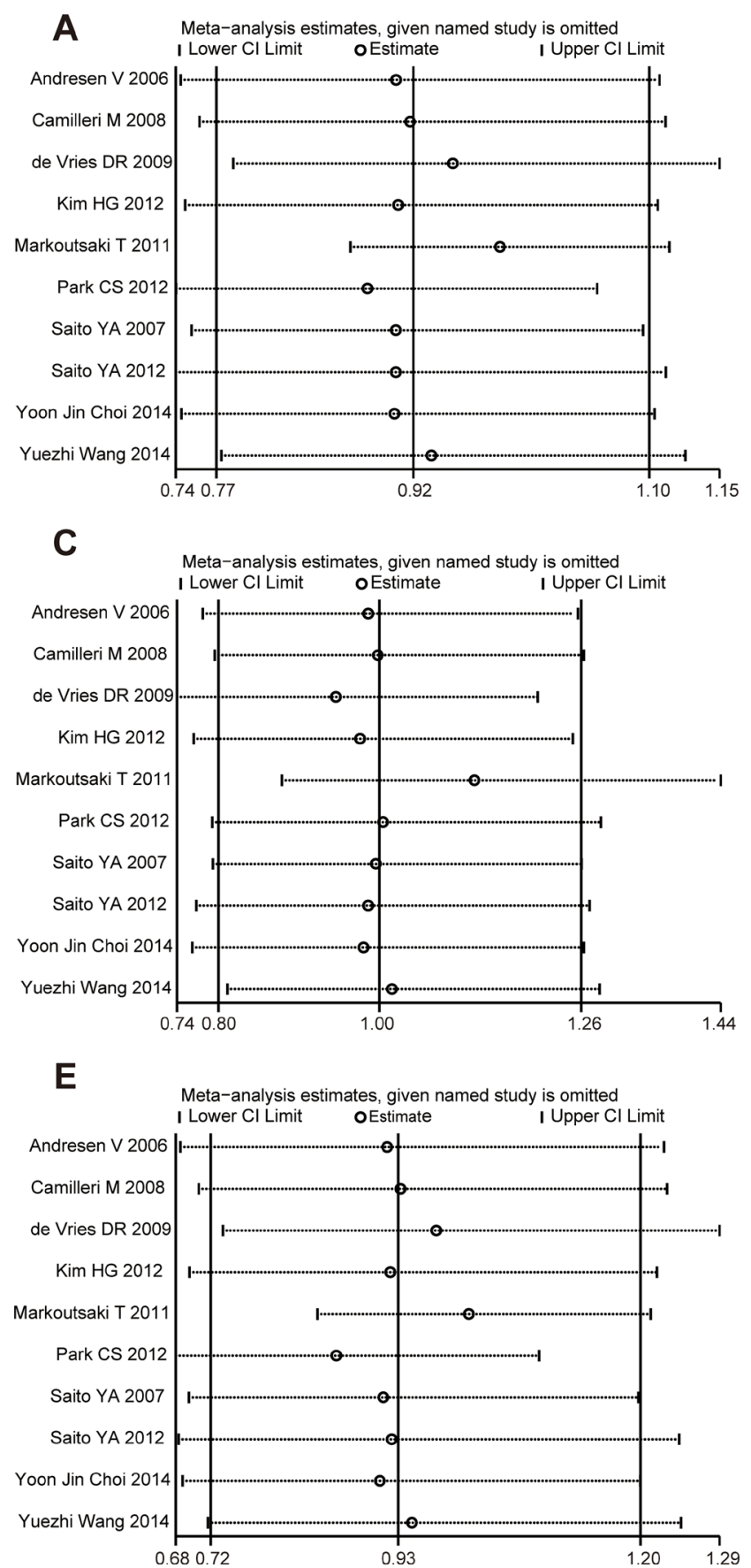

and IBS-M). The major reason of this discrepancy is that this previous meta-analysis did not include all the published articles and did not assess the association between this polymorphism and IBS subtypes with respect to ethnicity. In contrast, our meta-analysis included all the eleven relevant published studies with a larger sample size of cases and controls, which gave a greater statistical power to evaluate the association than the previous study. Additionally, our study included four studies in Asian group and four studies in Caucasian group to evaluate the

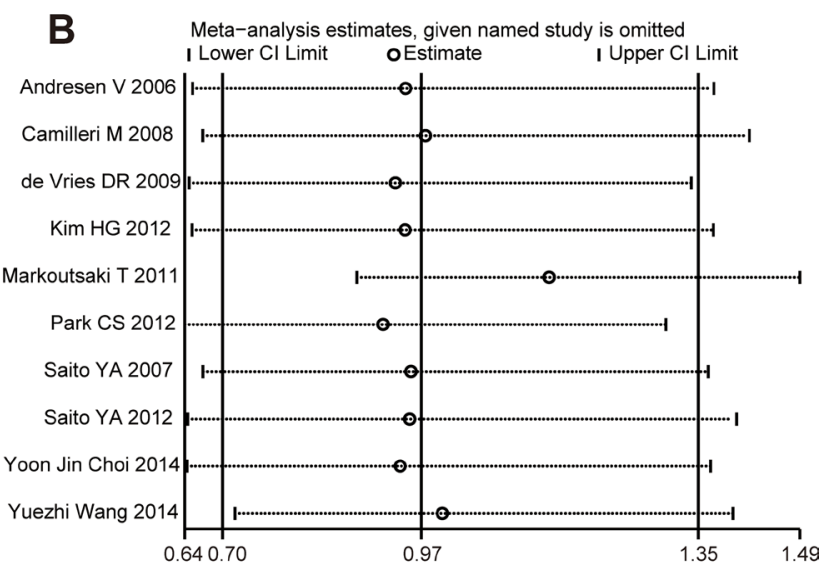

$\mathbf{D}$

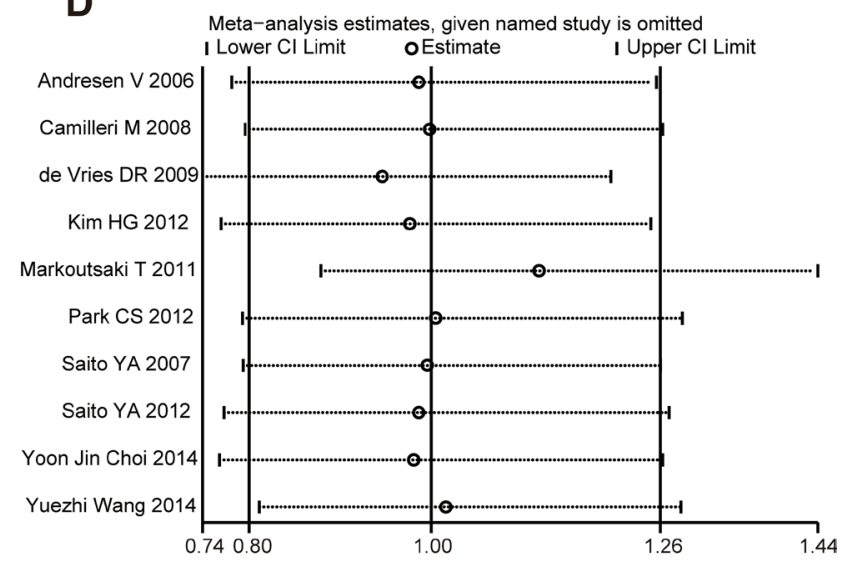

Figure 5: Sensitivity analysis of the association of GNB3 C825T and IBS in the different genetic models. (A) Allele model (C vs. T). (B) Codominant model (CC vs. TT). (C) Codominant model (CT vs. TT). (D) Dominant model (CC + CT vs. TT). (E) Recessive model $(\mathrm{CC}$ vs. TT + CT). 
association between $G N \beta 3$ C825T polymorphism and IBS subtypes, which gave a more detailed analysis to assay the association and showed a more reliable result.

To the best of our knowledge, this is the first metaanalysis to explore the relationships between $G N \beta 3$ C825T gene polymorphism and IBS and its subtypes with respect to ethnicity. The genotype distributions in all of the controls were consistent with HWE, except one for one study reported by Lee et al. [10]. However, the association was not significant change when excluded the study. The NOS results indicated that the included studies were credible. Moreover, sensitivity analysis did not significantly alter in overall and subgroup results under all genetic models. In addition, no evidence of publication bias was identified by either Begg's or Egger's tests. Taken together, the outcomes of our meta-analysis are relatively reliable and stable.

Nevertheless, there were some limitations in the current study. First, only articles in English and Chinese language were included; thus, studies written in other languages were neglected. Second, although we performed a systematic searching strategy to identify eligible studies, there was still probability that few studies so called "grey literatures" were not included. Third, due to the limited data, we did not carry out subgroup analysis to other factors, which may participate in the progression of IBS, such as age, infection, social psychology, and other living habits. Finally, IBS is a common gastrointestinal disorder in the human population; particularly in females (two thirds of patients are female). However, none of the original studies accounted for gene-gender interactions. Further studies are needed to clarify whether genderrelated differences affected the polymorphism of GN $\beta 3$ C825T and subsequent IBS.

In summary, this meta-analysis suggested that the $\mathrm{C}$ allele of $G N \beta 3$ C825T may be associated with a decreased risk of IBS-C, while the CC genotype of GN $\beta 3$ may be associated with increased IBS-D risk. However, due to the above-mentioned limitations, a well-designed largescale study that includes ethnicities, IBS subtypes and psychosocial factors is required to confirm the findings of the current meta-analysis.

\section{MATERIALS AND METHODS}

\section{Search strategy and selection criteria}

According to the Preferred Reporting Items for Systematic Reviews and Meta-Analyses (PRISMA) statement [32], we searched the related literature of the electronic records of the PubMed, Embase, Science Direct, Chinese National Knowledge Infrastructure (CNKI) and WANFANG databases prior to April 2017. The search terms included the following key words: ("Irritable bowel syndrome" or "IBS") AND ("polymorphism" or "allele" or "gene" or "mutation" or "variant") AND ("G protein beta3" or "G protein $\beta 3$ " or "GN $\beta 3$ "). Furthermore, the references of all retrieved articles were also checked by hand to identify additional potential studies. The languages were limited to English and Chinese. We inclusion all studies that (1) evaluated the association between $G N \beta 3$ polymorphism and the risk of IBS; (2) used a case control design; (3) provided sufficient data of allele and genotype frequencies of SNPs or required information could be calculated; and (4) if serial studies on the same population were published, only the most recent or the largest research study was included. Additionally, we excluded reviews, abstracts, and redundant and animal studies.

\section{Data extraction}

Two independent investigators extracted relevant data from all included studies on the basis of the inclusion criteria, and a third investigator verified them. The following information was extracted from all of enrolled studies: the surname of the first author, publication year, country of origin, ethnicity, sample size, genotyping method, and the GN $\beta 3$ genotype distributions and alleles in the case and control groups.

\section{Quality assessment}

The quality of included studies were assessed by two investigators independently on the basis of NewcastleOttawa Scale (NOS) [33], which based on three aspects: selection, comparability and exposure. Studies with a score of 5 points or higher were considered to be of high quality.

\section{Statistical analysis}

The HWE of the genotype distributions in the controls of the include studies were tested by the Chi-square test, $P<0.05$ was considered statistically significant. Studies with the controls not in HWE were subjected to a sensitivity analysis [34]. The power analysis was calculated by using the Power and Sample Size Program software [35]. The associations of the $G N \beta 3$ polymorphism with the risk of IBS was assessed by the pooled ORs with the corresponding 95\% CIs under the following genetic models: allele model $(\mathrm{C}$ vs. T), codominant model (CC vs. TT and CT vs. TT), dominant model (CC + CT vs. TT), and recessive model (CC vs. CT + TT). The heterogeneity between studies was determined by the Cochrane's $Q$-statistic test [36], and the inconsistency was quantified with the $I^{2}$ statistic. When $I^{2}>$ $50 \%$ or $P_{\mathrm{Q}} \leq 0.1$, which suggest substantial heterogeneity, a random-effects model (DerSimonian-Laird method) [37] was used; otherwise, the fixed-effects model (MantelHaenszel method) [32] was applied. Sensitivity analysis was conducted by sequentially omitting each study to evaluate the stability of statistical results. Furthermore, 
Begg's funnel plot and Egger's test [38] was used to evaluate the potential publication bias $(P<0.05$ was considered statistically significant). All analyses were conducted using the STATA 12.0 software packages.

\section{Abbreviations}

IBS:Irritable bowel syndrome; IBS-C:constipation predominant IBS; IBS-D:diarrhea predominant IBS; IBSM:mixture of diarrhea and constipation IBS; ORs:odds ratios; 95\% CIs:95\% confidence intervals; G-protein:Guanine nucleotide binding protein; GN $\beta 3$ :G-protein $\beta 3$ subunit gene; SNP:single nucleotide polymorphism; HWE:HardyWeinberg equilibrium; NOS:Newcastle- Ottawa Scale; MAF: minor allele frequencies; EAS:East Asian population; AMR:Ad Mixed American population; EUR:European population; PRISMA:Preferred Reporting Items for Systematic Reviews and Meta-Analyses; CNKI:Chinese National Knowledge Infrastructure.

\section{Author contributions}

Study Conception and Design: TMG, DBJ and DH. Acquisition of data: DH, TL and WMC. Preparation of Figures: DH, TL and YW. Preparation of tables: TL, DH, HYC and YW. Writing and revision of the manuscript: TMG and XLM.

\section{ACKNOWLEDGMENTS}

We thank the hospital for providing a good research platform for us, and thank the family for their support and understand in work and study.

\section{CONFLICTS OF INTEREST}

The authors declare no conflicts of interest.

\section{REFERENCES}

1. Chey WD, Kurlander J, Eswaran S. Irritable bowel syndrome: a clinical review. JAMA. 2015; 313:949-58. https://doi.org/10.1001/jama.2015.0954.

2. Sperber AD, Dumitrascu D, Fukudo S, Gerson C, Ghoshal UC, Gwee KA, Hungin APS, Kang JY, Minhu C, Schmulson M, Bolotin A, Friger M, Freud T, et al. The global prevalence of IBS in adults remains elusive due to the heterogeneity of studies: a Rome Foundation working team literature review. Gut. 2017; 66:1075-82. https://doi.org/10.1136/gutjnl-2015-311240.

3. Drossman DA. The functional gastrointestinal disorders and the Rome III process. Gastroenterology. 2006; 130:137790. https://doi.org/10.1053/j.gastro.2006.03.008.

4. Longstreth GF, Thompson WG, Chey WD, Houghton LA, Mearin F, Spiller RC. Functional bowel disorders. Gastroenterology. 2006; 130:1480-91. https://doi.org/10.1053/j.gastro.2005.11.061.

5. Holtmann G, Goebell H, Jockenhoevel F, Talley NJ. Altered vagal and intestinal mechanosensory function in chronic unexplained dyspepsia. Gut. 1998; 42:501-6.

6. Camilleri M. Peripheral mechanisms in irritable bowel syndrome. N Engl J Med. 2012; 367:1626-35. https://doi.org/10.1056/NEJMra1207068.

7. Zheng Z, Tang H. Decreased neuroplasticity may play a role in irritable bowel syndrome: implication from the comorbidity of depression and irritable bowel syndrome. J Neurogastroenterol Motil. 2015; 21:298-9. https://doi.org/10.5056/jnm14158.

8. Gazouli M, Wouters MM, Kapur-Pojskic L, Bengtson MB, Friedman E, Nikcevic G, Demetriou CA, Mulak A, Santos J, Niesler B. Lessons learned--resolving the enigma of genetic factors in IBS. Nat Rev Gastroenterol Hepatol. 2016; 13:77-87. https://doi.org/10.1038/nrgastro.2015.206.

9. de Vries DR, ter Linde JJ, van Herwaarden MA, Smout AJ, Samsom M. Gastroesophageal reflux disease is associated with the C825T polymorphism in the G-protein beta3 subunit gene (GNB3). Am J Gastroenterol. 2009; 104: 281-5. https://doi.org/10.1038/ajg.2008.139.

10. Lee HJ, Lee SY, Choi JE, Kim JH, Sung IK, Park HS, Jin CJ. $\mathrm{G}$ protein beta3 subunit, interleukin-10, and tumor necrosis factor-alpha gene polymorphisms in Koreans with irritable bowel syndrome. Neurogastroenterol Motil. 2010; 22:75863. https://doi.org/10.1111/j.1365-2982.2010.01496.x.

11. Markoutsaki T, Karantanos T, Gazouli M, Anagnou NP, Ladas SD, Karamanolis DG. Serotonin transporter and G protein beta 3 subunit gene polymorphisms in Greeks with irritable bowel syndrome. Dig Dis Sci. 2011; 56:3276-80. https://doi.org/10.1007/s10620-011-1726-7.

12. Park CS, Uhm JH. Polymorphisms of the Serotonin Transporter Gene and G-Protein beta3 Subunit Gene in Korean Children with Irritable Bowel Syndrome and Functional Dyspepsia. Gut Liver. 2012; 6:223-8. https://doi.org/10.5009/gnl.2012.6.2.223.

13. Melien O. Heterotrimeric $\mathrm{G}$ proteins and disease. Methods Mol Biol. 2007; 361:119-44. https://doi.org/10.1385/159745-208-4:119.

14. Siffert W. G-protein beta3 subunit $825 \mathrm{~T}$ allele and hypertension. Curr Hypertens Rep. 2003; 5:47-53.

15. Klenke S, Kussmann M, Siffert W. The GNB3 C825T polymorphism as a pharmacogenetic marker in the treatment of hypertension, obesity, and depression. Pharmacogenet Genomics. 2011; 21:594-606. https://doi. org/10.1097/FPC.0b013e3283491153.

16. Siffert W, Rosskopf D, Siffert G, Busch S, Moritz A, Erbel R, Sharma AM, Ritz E, Wichmann HE, Jakobs KH, Horsthemke B. Association of a human G-protein beta3 subunit variant with hypertension. Nat Genet. 1998; 18:458. https://doi.org/10.1038/ng0198-45.

17. Fang L, Zhou C, Bai S, Huang C, Pan J, Wang L, Wang X, Mao Q, Sun L, Xie P. The C825T Polymorphism of the 
G-Protein beta3 Gene as a Risk Factor for Depression: A Meta-Analysis. PLoS One. 2015; 10: e0132274. https://doi. org/10.1371/journal.pone.0132274.

18. Bullido MJ, Ramos MC, Ruiz-Gomez A, Tutor AS, Sastre I, Frank A, Coria F, Gil P, Mayor F Jr, Valdivieso F. Polymorphism in genes involved in adrenergic signaling associated with Alzheimer's. Neurobiol Aging. 2004; 25:853-9. https://doi.org/10.1016/j. neurobiolaging.2003.10.006.

19. Bagos PG, Elefsinioti AL, Nikolopoulos GK, Hamodrakas SJ. The GNB3 C825T polymorphism and essential hypertension: a meta-analysis of 34 studies including 14,094 cases and 17,760 controls. J Hypertens. 2007; 25:487-500. https://doi.org/10.1097/HJH.0b013e328011db24.

20. Hwang IC, Kim KK, Ahn HY, Suh HS, Oh SW. Effect of the G-protein beta3 subunit $825 \mathrm{~T}$ allele on the change of body adiposity in obese female. Diabetes Obes Metab. 2013; 15:284-6. https://doi.org/10.1111/dom.12023.

21. Mitchell A, Pace M, Nurnberger J, Wenzel RR, Siffert W, Philipp T, Schafers RF. Insulin-mediated venodilation is impaired in young, healthy carriers of the $825 \mathrm{~T}$ allele of the G-protein beta3 subunit gene (GNB3). Clin Pharmacol Ther. 2005; 77:495-502. https://doi.org/10.1016/j. clpt.2005.03.002.

22. Safarinejad MR, Safarinejad S, Shafiei N, Safarinejad S. G-protein beta3 subunit gene $825 \mathrm{C} / \mathrm{T}$ polymorphism and its association with the presence, severity, and duration of vasculogenic erectile dysfunction. Fertil Steril. 2013; 99:69-75. https://doi.org/10.1016/j.fertnstert.2012.08.033.

23. Holtmann G, Siffert W, Haag S, Mueller N, Langkafel M, Senf W, Zotz R, Talley NJ. G-protein beta 3 subunit 825 $\mathrm{CC}$ genotype is associated with unexplained (functional) dyspepsia. Gastroenterology. 2004; 126:971-9.

24. Andresen V, Camilleri M, Kim HJ, Stephens DA, Carlson PJ, Talley NJ, Saito YA, Urrutia R, Zinsmeister AR. Is there an association between GNbeta3-C825T genotype and lower functional gastrointestinal disorders? Gastroenterology. 2006; 130:1985-94. https://doi. org/10.1053/j.gastro.2006.03.017.

25. Saito YA, Larson JJ, Atkinson EJ, Ryu E, Almazar AE, Petersen GM, Talley NJ. The role of 5-HTT LPR and GNbeta3 $825 \mathrm{C}>\mathrm{T}$ polymorphisms and gene-environment interactions in irritable bowel syndrome (IBS). Dig Dis Sci. 2012; 57:2650-7. https://doi.org/10.1007/s10620-012-2319-9.

26. Kim HG, Lee KJ, Lim SG, Jung JY, Cho SW. G-Protein Beta3 Subunit C825T Polymorphism in Patients With Overlap Syndrome of Functional Dyspepsia and Irritable Bowel Syndrome. J Neurogastroenterol Motil. 2012; 18:205-10. https://doi.org/10.5056/jnm.2012.18.2.205.
27. Saito YA, Locke GR 3rd, Zimmerman JM, Holtmann G, Slusser JP, de Andrade M, Petersen GM, Talley NJ. A genetic association study of 5-HTT LPR and GNbeta3 C825T polymorphisms with irritable bowel syndrome. Neurogastroenterol Motil. 2007; 19:465-70. https://doi. org/10.1111/j.1365-2982.2007.00905.x.

28. Camilleri M, Busciglio I, Carlson P, McKinzie S, Burton D, Baxter K, Ryks M, Zinsmeister AR. Pharmacogenetics of low dose clonidine in irritable bowel syndrome. Neurogastroenterol Motil. 2009; 21:399-410. https://doi. org/10.1111/j.1365-2982.2009.01263.x.

29. Wang Y, Wu Z, Qiao H, Zhang Y. A genetic association study of single nucleotide polymorphisms in GNbeta3 and COMT in elderly patients with irritable bowel syndrome. Med Sci Monit. 2014; 20:1246-54. https://doi.org/10.12659/MSM.890315.

30. Choi YJ, Hwang SW, Kim N, Park JH, Oh JC, Lee DH. Association Between SLC6A4 Serotonin Transporter Gene Lainked Polymorphic Region and ADRA2A -1291C $>$ G and Irritable Bowel Syndrome in Korea. J Neurogastroenterol Motil. 2014; 20:388-99. https://doi.org/10.5056/jnm14020.

31. Pan ZG, Xiao C, Su DX. No association of G-protein beta polypeptide 3 polymorphism with irritable bowel syndrome: evidence from a meta-analysis. World J Gastroenterol. 2014; 20:6345-52. https://doi.org/10.3748/wjg.v20.i20.6345.

32. Mantel N, Haenszel W. Statistical aspects of the analysis of data from retrospective studies of disease. J Natl Cancer Inst. 1959; 22:719-48.

33. Stang A. Critical evaluation of the Newcastle-Ottawa scale for the assessment of the quality of nonrandomized studies in meta-analyses. Eur J Epidemiol. 2010; 25:603-5. https:// doi.org/10.1007/s10654-010-9491-z.

34. Thakkinstian A, McElduff P, D'Este C, Duffy D, Attia J. A method for meta-analysis of molecular association studies. Stat Med. 2005; 24:1291-306. https://doi.org/10.1002/ sim.2010.

35. Dupont WD, Plummer WD Jr. Power and sample size calculations. A review and computer program. Control Clin Trials. 1990; 11:116-28.

36. Colditz GA, Burdick E, Mosteller F. Heterogeneity in metaanalysis of data from epidemiologic studies: a commentary. Am J Epidemiol. 1995; 142:371-82.

37. DerSimonian R. Meta-analysis in the design and monitoring of clinical trials. Stat Med. 1996; 15:1237-48; discussion 49-52. https://doi.org/10.1002/(SICI)10970258(19960630)15:12<1237::AID-SIM301>3.0.CO;2-N.

38. Egger M, Davey Smith G, Schneider M, Minder C. Bias in meta-analysis detected by a simple, graphical test. BMJ. 1997; 315:629-34. 